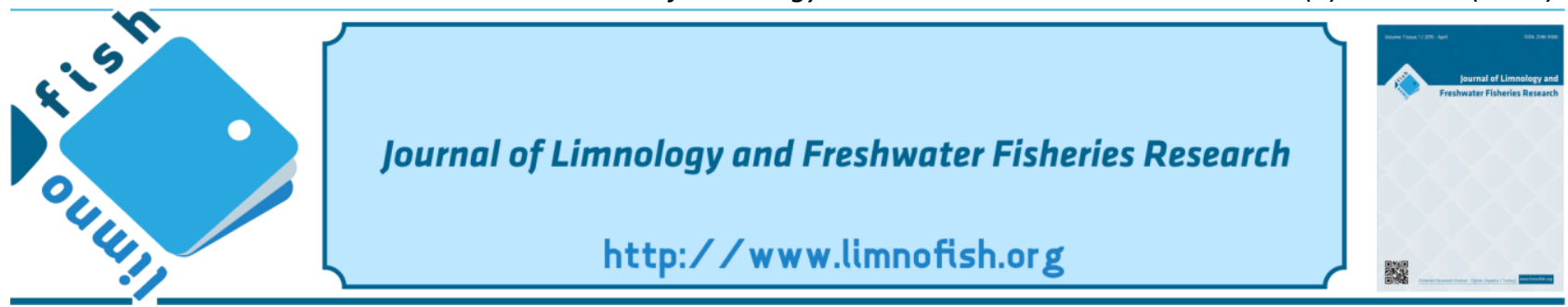

\title{
Evaluation of Tench (Tinca tinca L., 1758) Meat as Fish Cake and Determination of Shelf Life
}

\author{
Kadir ÇAPKIN ${ }^{1}$ (D) İlker ATİK $^{2^{*}}$ (D), Azize ATIKK ${ }^{3}$ (D), Ramazan ŞEVIK ${ }^{4}$ (iD)
}

${ }^{1}$ Republic of Turkey, Ministry of Agriculture and Forestry, Fisheries Research Institute, Eğirdir, Isparta, Turkey

${ }^{2}$ Afyon Kocatepe University, Afyon Vocational School, Food Technology Program, Afyonkarahisar, Turkey

${ }^{3}$ Afyon Kocatepe University, Sultandagı Vocational School, Food Technology Program, Sultandağı, Afyonkarahisar, Turkey

${ }^{4}$ Afyon Kocatepe University, Faculty of Engineering, Department of Food Engineering, Afyonkarahisar, Turkey

\section{A B STRACT}

In this research, the suitability of tench (Tinca tinca L., 1758) for the production of fish cake and changes in nutrient components were determined. The supplied fish materials were minced followed by forming into fish cakes with the addition of various additives. Chemical and organoleptic analyzes of the minced fish and fish cakes were made. Also, thiobarbutyric acid $(T B A)$, total volatile basic nitrogen $(T V B-N), \mathrm{pH}$ parameters were determined and total mesophilic aerobic bacteria (TMA), total psychophilic bacteria (TPA), coliform group bacteria, and yeast-mold counts were performed in fish cakes on the 1., 4., 7. and 10. days of the storage at $4 \pm 1{ }^{\circ} \mathrm{C}$. According to the organoleptic analysis findings, the fish cakes obtained from tench were considered suitable for consumption. TBA, TVB$\mathrm{N}, \mathrm{pH}$ values, and microbiological analysis results of storage have shown that deterioration occurs as storage time increases. Especially the changes after the 7th day of storage are statistically significant $(\mathrm{p}<0.05)$. As a result of the research, it is concluded that fish cakes made using tench can contribute to the economy. It was determined that the obtained fish cakes which were stored at $4 \pm 1^{\circ} \mathrm{C}$ maintained the good quality parameters until the 7 th day while they deteriorated after the 10th day of the storage.

\section{ARTICLE INFO}

\section{RESEARCH ARTICLE}

$\begin{array}{ll}\text { Received } & : 05.06 .2020 \\ \text { Revised } & : 28.08 .2020 \\ \text { Accepted } & : 01.09 .2020 \\ \text { Published } & : 29.12 .2020\end{array}$

DOI:10.17216/LimnoFish.746026

\section{* CORRESPONDING AUTHOR}

ilkeratik@hotmail.com

Phone : +90272 2182924

Keywords: Tench, fish cake, shelf life

\section{Kadife Balığı (Tinca Tinca L., 1758) Etinin Balık Köftesi Olarak Değerlendirilmesi ve Raf Ömrünün Belirlenmesi}

Öz: Bu araștırmada kadife balığının (Tinca tinca L., 1758) köfte yapımına uygunluğu ve besin bileșenlerindeki değișimler belirlenmiştir. Tedarik edilen balık filetoları kıyma haline getirilerek çeşitli katkı maddelerinin eklenmesiyle balık köftesi yapılmıştır. Balık kıyması ve balık köftesinin kimyasal ve organoleptik analizleri yapılmıştır. Ayrıca balık köftesinde $4 \pm 1{ }^{\circ} \mathrm{C}$ 'de depolamanın 1., 4., 7. ve 10. günlerinde tiyobarbütirik asit $(T B A)$, toplam uçucu bazik azot - $(T V B-N)$, pH parametrelerine bakılmıştır. Toplam mezofilik aerobik bakteri (TMA), toplam psikofilik bakteri (TPA), koliform grubu bakteri ve maya-küf sayımı yapılmıştır. Organoleptik analiz bulgularına göre, kadife balığından elde edilen köfte tüketime uygun görmüștür. $T B A, T V B-N, \mathrm{pH}$ değerleri ve depolamanın mikrobiyolojik analiz sonuçları depolama süresi arttıkça bozulma olduğunu göstermiştir. Özellikle depolamanın 7. gününden sonraki değişimler istatistiksel açıdan önemlidir ( $p<0,05)$. Araştırma sonucunda, kadife balığı kullanılarak yapılan balık köftesinin ekonomiye katkı sağlayabileceği sonucuna varılmıştır. Elde edilen balık köftelerinin, $4 \pm 1^{\circ} \mathrm{C}^{\prime}$ de depolama sürecinde iyi kalite özelliklerinin 7. güne kadar korunduğu ve depolamanın 10. gününden sonra kötüleştiğ tespit edilmiştir.

Anahtar kelimeler: Kadife balığı, balık köftesi, raf ömrü

How to Cite

Çapkın K, Atik İ, Atik A, Şevik R. 2020. Evaluation of Tench (Tinca tinca L., 1758) Meat as Fish Cake and Determination of Shelf Life LimnoFish. 6(3): 251-260. doi: 10.17216/LimnoFish.746026

\section{Introduction}

Nowadays, advances in technology have enabled the awareness of the consumer and have brought the brainpower to the fore in most occupational groups.
As a result, the orientation towards the food rich in protein and unsaturated fatty acids, easily digestible has increased. Fisheries is the food group that meets the expectations of the consumer while fish meat 
takes the first place among all aquaculture. Fish meat is a sufficient foodstuff due to its high content of essential nutrients such as protein, unsaturated fatty acids, and essential amino acids required for the body (Duman and Dartay 2007).

Red meat consumption as a source of protein is more common in our country. Consumption of red meat is quite high especially in fast working life as meatballs because of the reason that usage of meatballs in some meat products as hamburgers, etc. is necessary. However, alternative sources for burgers and meatballs are being investigated because of the concerns that high cholesterol in red meat may cause cardiovascular diseases. Fish meat may be an alternative to red meat because of its low cholesterol level and high omega-3 fatty acid content that prevents cardiovascular disease (Balıkçı et al. 2018).

Species belong to the Cyprinidae family is very common in Turkey's freshwater. 226 fish species and subspecies belonging to 27 families were found to live in inland waters of the country. 170 of them live in freshwater. 108 of these fish belong to the family of Cyprinidae (Hamalosmanoğlu and Kuru 2004).

Tench (Tinca tinca, Linnaeus 1758) is a freshwater cyprinid and a benthos-eating omnivorous widely lives in parts of Europe and Asia (Secci et al. 2018). It has great potential for the aquaculture sector. The natural distribution of this fish was undefined for centuries since it was understood that it was comestible and suitable for culture and transport in middle ages (Avlijaš et al. 2018).

Fish cake is a fish product obtained by adding spices after cleaning, boiling, and mincing the fish meat (Öksüztepe et al. 2010; Özpolat and Çoban 2012). Different recipes are given for the production of fish cakes and these recipes are applied by taking into consideration the characteristics of the raw material. In the study in which fish cakes were produced from carp (Cyprinus carpio), fish were filleted after skinning and boiled in boiling water for 1-2 minutes to separate meat from a fishbone. After the process of separation of meat from fishbone, groundfish were obtained by passing fish meat from a grinder with a hole diameter of $3 \mathrm{~mm}$. To give the product a certain elasticity, $0.3 \%$ sodium polyphosphate and to enhance the flavour, $0.9 \%$ salt, $0.4 \%$ black pepper, $0.5 \%$ cumin, $0.5 \%$ red pepper, and $1.3 \%$ parsley were added to the experimental groups. Then, different groups were added to the fish cakes and 5 groups were formed together with the control group (Group A: $6 \%$ onion; Group B: $6 \%$ onion $+4 \%$ sunflower oil; Group C: $1.4 \%$ garlic; Group D: $1.4 \%$ garlic + $4 \%$ sunflower oil, Group E: Control group). The products were shaped by placing $6 \mathrm{~cm}$ diameter and $1 \mathrm{~cm}$ depth of stainless steel circle molds (Yanar and Fenercioğlu 1999).
In a study about the investigation of some quality parameters of fish cakes made from raw and boiled fish meat, fish were decapitated, eviscerated, and minced orderly. Mixed seasonings (black pepper, allspice, cumin) and additives (starch, garlic) were added into the minced fish meat, then kneaded and finally given fish cake shapes. The fish cakes were prepared with an average of $25 \mathrm{~g}$ weight, packed with stretch film by the placement of 3 pieces each on styrofoam plates and soted at $+4 \pm 1{ }^{\circ} \mathrm{C}$ (Akkuş et al. 2004).

In a research conducted in the aquaculture processing plants which process the zander $(S$. lucioperca) and the tench fish fillets, the evaluation of fillet residues that do not conform to the calibration as fish cakes to contribute to the economy was investigated. Zander and tench fillet residues were obtained from local enterprises as material. Fish cakes were made after mincing these supplied materials and the addition of various additives (Ünlüsayın et al. 2002).

In this study, the processability of tench, which is common in Turkey's inland waters was aimed to evaluate differently. In this way, the meat of tench which is not preferred by consumers should be approved by converting into fishcakes. In addition to this, depending on a consumer's pleasure it was aimed to extend the shelf life of the tench meat and develop a new product that has gained economic value.

\section{Materials and Methods \\ Materials}

In the study, a total of 100 tenches (Tinca tinca) with a mean length of $24 \pm 1 \mathrm{~cm}$ and a weight of 190 $\pm 20 \mathrm{~g}$ were used which caught from Lake Beyşehir (Konya, Turkey). Additives and spices used in the production of fish cakes were supplied from the local market of Eğirdir (Isparta, Turkey).

\section{Fishing and transport of the fish}

T. tinca samples forming the material of this study were fished from Lake Beyşehir by the operation of hauling with extension nets. After that, fish that were in the same size group were selected and brought to the Eğirdir Fisheries Research Institute Food Laboratory for assay.

\section{Preparation of fish cakes}

The fish to be used in the study were eviscerated and washed with plenty of water. The washing process was made carefully not to remain any residues as blood, mucus, and so on. Cleaned fish were filleted and the groundfish were obtained by passing fish meat from a grinder with a hole diameter of $3 \mathrm{~mm} .3$ different formulations were prepared by adding additives and spices to the groundfish. The 
preparation of fish cakes were similar to known methods (Damarlı et al. 1992; Avc1 1996). All fish cakes were prepared by shaping in which each of them was put in a $10 \mathrm{~g}$ weight, $5 \mathrm{~cm}$ diameter and 0.5 $\mathrm{cm}$ deep stainless steel circle molds. In preparation of control group fish cakes in addition to the groundfish, $1 \%$ salt, $0.5 \%$ black pepper, $0.5 \%$ red pepper, 0.5 $\%$ cumin, $1 \%$ parsley, $10 \%$ tail fat $10 \%$ semolina were added. In addition to the control group; $1 \%$ thyme was added into the first fish cake group and 1 $\%$ ginger was added into the second fish cake group. After the fish cakes were prepared by 3 different formulations, they were evaluated separately by 10 panelists. The fish cakes were packaged with aluminum foil and stored at $4 \pm 1^{\circ} \mathrm{C}$ for $1,4,7,10$ days (under refrigerator conditions). Then, samples were taken for each stated day and shelf life was determined for these products by examining sensory, chemical and microbiological changes. The preparation of the fish cakes was carried out according to the following product processing flow diagram (Figure 1).

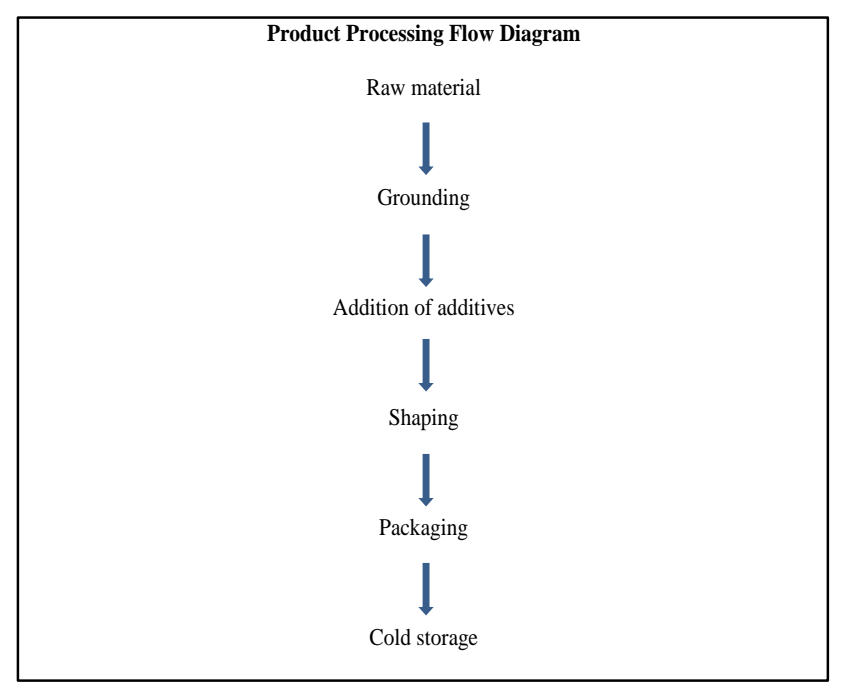

Figure 1. Product processing flow diagram.

All analyzes in the study were carried out in fresh fish and fish cake samples taken periodically on the $1 \mathrm{st}, 4 \mathrm{th}, 7 \mathrm{th}$, and 10th days of the storage.

\section{Biometrical measurements}

The meat yield of the fish brought to the laboratory was calculated by measuring the lengths by $\mathrm{mm}$ graduated of a gauge and weights by a scale with a sensitivity of $0.01 \mathrm{~g}$ (Dikel and Çelik 1998).

\section{Determination of $\mathbf{p H}$}

$\mathrm{pH}$ measurement was conducted according to TSE 2002. Samples (10 g) were taken periodically from fresh fish and fish cakes during storage and homogenized with the help of mixer. Then measurements were carried out at $16 \pm 1{ }^{\circ} \mathrm{C}$ with WTW branded 320 sets of digital pH-meter $(\mathrm{Er}$ 2010).

\section{Chemical composition analysis}

Determination of moisture was carried out according to TS $1743\left(110 \pm 1{ }^{\circ} \mathrm{C}\right)$ (Anonymous 1974a) while deternination of inorganic matter (crude ash) was carried out according to TS $1746\left(550 \pm 1{ }^{\circ} \mathrm{C}\right)$ (Anonymous 1974b) in fresh fish, processed and stored fish cake samples. Additionally, crude protein analysis was carried out according to Kjeldahl Method (Nx6.25), (Anonymous 1983) and crude oil analysis was carried out according to Soxhlet Method (Keskin 1975).

\section{Determination of Thiobarbituric Acid Reactive Substances (TBARS)}

In this analysis, a method based on the occurrence of red color as a result of heating of thiobarbituric acid with malonaldehyde which is formed by oxidation of unsaturated fatty acids was used. The amount of malonaldehyde specified as TBA number was determined as spectrophotometric (at $538 \mathrm{~nm}$ wavelength) and the results were given in $\mathrm{mgMA} / \mathrm{kg}$ (Varlik et al. 1993).

\section{Determination of Total Volatile Basic Nitrogen (TVB-N) \\ Total volatile basic nitrogen determination of fresh and processed fish meat was made according to the Lucke-Geidel method modified by Antonacopoulas and Vyncke (1989) and the results were given in $\mathrm{mg} / 100 \mathrm{~g}$ (İnal 1992).}

\section{Microbiological Analysis}

Preparation of samples for microbiological analysis

$25 \mathrm{~g}$ of fish meat was weighed with the help of sterile forceps, scalpel and scissors in aseptic conditions and $225 \mathrm{ml}$ of buffered peptoned water (Merck 7228) was added onto it. It was then homogenized in 2-3 minutes pre-sterilized blender and diluted 10-fold. Cultivations were carried out by using pour plate method. For cultivation two parallels were used from each dilution. 30-300 coloniesincluding plaques in Petri dishes were enumerated (Refai 1979; Varlık et al. 1993).

Total mesophilic aerobic (TMA) bacteria count

Plate Count Agar (Merck 5463) was used for the count of total mesophilic aerob bacteria. After cultivation petri dishes were incubated at $30 \pm 1{ }^{\circ} \mathrm{C}$ for 72 hours and forming colonies were enumerated at the end of the incubation (Refai 1979; Varlık et al. 1993).

\section{Total psychrophilic aerobic (TPA) bacteria} count

Plate Count Agar (Merck 5463) was used for the count of total psychrophilic aerob bacteria. Forming colonies were enumerated after 72 hours of incubation at $22 \pm 1{ }^{\circ} \mathrm{C}$ (Anonymous 1993). 


\section{Coliform bacteria count}

Violet Red Bile Agar (Merck 1406) was used as the medium. Plates were evaluated by incubating at $37 \pm 1{ }^{\circ} \mathrm{C}$ for 24 hours and counted bold red coloured colonies (Kocatepe et al. 2011).

\section{Yeast and mould count}

Potato Dextrose Agar (Merck 10130), which was adjusted to $\mathrm{pH} 3.5$ by using $10 \%$ tartaric acid, was used as the medium. Plates were enumerated after incubation at $22 \pm 1{ }^{\circ} \mathrm{C}$ for 3-5 days (Anonymous 1983; Varlık et al. 1993).

\section{Sensory analysis}

In the sensory analyzes, the appearance, odor, texture, taste and general appreciation of the fish cakes were evaluated by the panellists with a score of 10 points in compliance with the hedonic scale. According to this, 10 points were evaluated as very good, 5 points were insignificant, and 4 points and under were inconsumable (Haq et al. 2013).

\section{Statistical analysis}

The data obtained from the study were subjected to the variance analysis (F-test) with JMP program, and the means for the calculated parameters were compared with the LS Means Student T Multiple Comparison Test. The significance level was chosen as $\mathrm{p}<0.05$.

\section{Results}

The meat yield rates of biometric measured samples were determined by seperating the viscera, head, skeleton, skin. Accordingly, the yield was determined as $43.769 \pm 0.670 \%$ (Table 1 ).

Table 1. Meat yield of tench (T. tinca L. 157) samples.

\begin{tabular}{lc} 
Weight $(\mathrm{g})$ & $193.275 \pm 16.970$ \\
Total length $(\mathrm{cm})$ & $24.475 \pm 0.848$ \\
Fork length $(\mathrm{cm})$ & $23.274 \pm 0.707$ \\
Viscera $(\%)$ & $11.987 \pm 1.137$ \\
Head $(\%)$ & $16.693 \pm 0.621$ \\
Meat $(\%)$ & $43.769 \pm 0.670$ \\
Skeleton $(\%)$ & $13.998 \pm 0.602$ \\
Skin $(\%)$ & $13.308 \pm 0.488$ \\
\hline
\end{tabular}

The results of sensory analysis of the fish cakes are given in Table 2 .

Table 2. Sensory analysis of fish cake.

\begin{tabular}{clll}
\hline Panellists & Control* & Group 1* & Group 2* \\
\hline Day 0 & $8.26^{\mathrm{b}}$ & $8.18^{\mathrm{b}}$ & $9.05^{\mathrm{a}}$ \\
Day 1 & $8.32^{\mathrm{b}}$ & $8.15^{\mathrm{b}}$ & $9.24^{\mathrm{a}}$ \\
Day 4 & $8.17^{\mathrm{b}}$ & $8.19^{\mathrm{b}}$ & $9.31^{\mathrm{a}}$ \\
Day 7 & $7.26^{\mathrm{b}}$ & $7.51^{\mathrm{a}}$ & $7.2^{\mathrm{b}}$ \\
Day 10 & $4.89^{\mathrm{a}}$ & $4.20^{\mathrm{b}}$ & $4.25^{\mathrm{b}}$
\end{tabular}

*Different superscript letters in the same line indicate significant difference between means $(\mathrm{p}<0.05)$.

As a result of the sensory analysis of the products obtained, a large part of the panelists liked fish cakes in terms of taste, smell, texture and appearance. Obtained fish cakes got between 8.18 and 9.05 on a ten point scale as a result of first sensory analysis. Second group fish cakes were the most admired group with 9.05 points. The sensory values of the fish cakes stored in the cold decreased depending on the storage period.

In ground fish, water was found to be 83.15 , crude protein was 13.07 , fat 1.14 , inorganic matter was 1.89 , carbohydrate was 1.21 in percentages. In the control group water was found to be in amount of 70.69 , crude protein 10.85 , fat 7.11 , inorganic matter 3.95 , carbohydrate 8.17 while in the first group water was 70.29 , crude protein 10.72 , fat 7.17 , inorganic matter 4.14 , carbohydrate 8.25 and in the second group water was 70.11 , crude protein 10.56, fat 7.11, inorganic matter 4.05 , carbohydrate 8.21 .

Chemical compositions of ground fish and fish cakes are given in Table 3.

Table 3. Chemical compositions of ground fish and fish cakes.

\begin{tabular}{clllc}
\hline Chemical Composition & $\begin{array}{l}\text { Ground Fish* } \\
\mathbf{x} \pm \mathbf{S H}\end{array}$ & $\begin{array}{l}\mathbf{C o n t r o l}^{*} \\
\mathbf{x} \pm \mathbf{S H}\end{array}$ & $\begin{array}{l}\text { Group 1* } \\
\mathbf{x} \pm \mathbf{S H}\end{array}$ & $\begin{array}{c}\text { Group } \\
\mathbf{x} \pm \mathbf{S H}\end{array}$ \\
\hline Water \% & $83.15 \pm 1.10^{\mathrm{a}}$ & $70.69 \pm 1.14^{\mathrm{b}}$ & $70.29 \pm 1.21^{\mathrm{b}}$ & $70.11 \pm 1.35^{\mathrm{b}}$ \\
Protein \% & $13.07 \pm 1.09^{\mathrm{a}}$ & $10.85 \pm 1.23^{\mathrm{b}}$ & $10.72 \pm 1.66^{\mathrm{b}}$ & $10.56 \pm 1.01^{\mathrm{b}}$ \\
Fat \% & $1.14 \pm 0.41^{\mathrm{b}}$ & $7.11 \pm 0.12^{\mathrm{a}}$ & $7.17 \pm 0.29^{\mathrm{a}}$ & $7.03 \pm 0.36^{\mathrm{a}}$ \\
InorganicMatter \% & $1.89 \pm 0.2^{\mathrm{b}}$ & $3.95 \pm 0.30^{\mathrm{a}}$ & $4.14 \pm 0.63^{\mathrm{a}}$ & $4.05 \pm 0.51^{\mathrm{a}}$ \\
Carbohydrate \% & $1.21 \pm 0.42^{\mathrm{b}}$ & $8.17 \pm 1.53^{\mathrm{a}}$ & $8.25 \pm 0.56^{\mathrm{a}}$ & $8.20 \pm 0.54^{\mathrm{a}}$ \\
\hline
\end{tabular}

*Different superscript letters in the same line indicate significant difference between means $(\mathrm{p}<0.05)$. 
Chemical and microbiological analysis results of fish cake are given in Table 4 and Table 5. According to the results of the analysis made in ground fish; TBA was found to be $1.05 \pm 0.30$, TVB-N was 10.4 \pm 1.09 and $\mathrm{pH}$ was $6.25 \pm 0.39$.
In microbiological analysis performed in ground tench fish, the count of TMAB was detected as 4.462 $\pm 0.023 \log \mathrm{cfu} / \mathrm{g}$, TPA was $3.726 \pm 0.016 \log \mathrm{cfu} / \mathrm{g}$, coliform bacteria was $1.301 \pm 0.026 \mathrm{log} \mathrm{cfu} / \mathrm{g}$ and yeast-mold was $1.079 \pm 0.009 \log \mathrm{cfu} / \mathrm{g}$.

Table 4. Chemical analysis results of ground fish.

\begin{tabular}{cccc}
\hline Chemical Analysis & TBA & TVB-N & $\mathrm{pH}$ \\
& $\mathrm{x} \pm \mathrm{SH}$ & $\mathrm{x} \pm \mathrm{SH}$ & $\mathrm{x} \pm \mathrm{SH}$ \\
\hline Ground Fish & $1.05 \pm 0.30$ & $10.4 \pm 1.09$ & $6.25 \pm 0.39$ \\
\hline
\end{tabular}

Table 5. Microbiological analysis results of ground fish.

\begin{tabular}{|c|c|c|c|c|}
\hline Microbiological Analysis & $\begin{array}{l}\text { TMA } \\
\mathbf{x} \pm \text { SH } \\
\end{array}$ & $\begin{array}{c}\text { TPA } \\
\mathbf{x} \pm \text { SH } \\
\end{array}$ & $\begin{array}{c}\text { COLIFORM } \\
\mathbf{x} \pm \mathrm{SH}\end{array}$ & $\begin{array}{c}\text { YEAST - MOULD } \\
\mathrm{x} \pm \mathrm{SH}\end{array}$ \\
\hline Ground Fish & $4.462 \pm 0.023$ & $3.726 \pm 0.016$ & $1.301 \pm 0.026$ & $1.079 \pm 0.009$ \\
\hline
\end{tabular}

The TBA values of fish cakes were increased according to storage time. Time dependent TBA changes in fish cakes are given in Table 6. TBA values of the product ranged from $1.43 \pm 0.18$ to 8.51 \pm 0.33 (mg malonaldehyde $/ \mathrm{kg}$ ) at $+4 \pm 1{ }^{\circ} \mathrm{C}$ during storage. In a very good material TBA values should be less than 3, and in a good material should not be more than 5 . The consumption limit value is between 7-8 (Duman and Özpolat 2012; Varlık et al. 1993).
The TVB-N values of fish cakes were increased according to storage time. Time dependent TVB-N changes in fish cakes are given in Table 7. The TVB-N values of the product increased during storage and ranged from $11.33 \pm 0.97$ to 37.37 $\pm 0.38 \mathrm{mg} / 100 \mathrm{~g}$ at $+4 \pm 1{ }^{\circ} \mathrm{C}$. The difference of TVB-N change between the products on the 4th, 7 th and 10th days of the storage was significant $(\mathrm{p}<0.05)$.

Table 6. Time dependent TBA changes in fish cakes (mg malonaldehyde/kg).

\begin{tabular}{lccc}
\hline Days & $\begin{array}{c}\text { Control }^{*} \\
\mathbf{x} \pm \mathbf{S H}\end{array}$ & $\begin{array}{c}\text { Group 1* } \\
\mathbf{x} \pm \mathbf{S H}\end{array}$ & $\begin{array}{c}\text { Group 2 }^{*} \\
\mathbf{x} \pm \mathbf{S H}\end{array}$ \\
\hline Day 0 & $1.43 \pm 0.101^{\mathrm{b}}$ & $1.58 \pm 0.138^{\mathrm{a}}$ & $1.56 \pm 0.194^{\mathrm{a}}$ \\
Day 1 & $2.88 \pm 0.153^{\mathrm{b}}$ & $3.03 \pm 0.143^{\mathrm{a}}$ & $3.04 \pm 0.136^{\mathrm{a}}$ \\
Day 4 & $4.97 \pm 0.101^{\mathrm{b}}$ & $5.51 \pm 0.140^{\mathrm{a}}$ & $5.47 \pm 0.063^{\mathrm{a}}$ \\
Day 7 & $6.81 .13 \pm 0.112^{\mathrm{b}}$ & $7.5 \pm 0.180^{\mathrm{a}}$ & $7.2 \pm 0.106^{\mathrm{ab}}$ \\
Day 10 & $8.26 \pm 0.077^{\mathrm{b}}$ & $8.39 \pm 0.154^{\mathrm{ab}}$ & $8.51 \pm 0.187^{\mathrm{a}}$ \\
\hline
\end{tabular}

*Different superscript letters in the same line indicate significant difference between means $(\mathrm{p}<0.05)$.

Table 7. Time dependent TVB-N changes in fish cakes $(\mathrm{mg} / 100 \mathrm{~g})$.

\begin{tabular}{lccc}
\hline Days & $\begin{array}{c}\text { Control* } \\
\mathbf{x} \pm \mathbf{S H}\end{array}$ & $\begin{array}{c}\text { Group 1* } \\
\mathbf{x} \pm \mathbf{S H}\end{array}$ & $\begin{array}{c}\text { Group 2* } \\
\mathbf{x} \pm \mathbf{S H}\end{array}$ \\
\hline Day 0 & $11.33 \pm 0.560^{\mathrm{a}}$ & $11.37 \pm 0.317^{\mathrm{a}}$ & $11.33 \pm 0.664^{\mathrm{a}}$ \\
Day 1 & $13.53 \pm 0.520^{\mathrm{b}}$ & $13.6 \pm 0.529^{\mathrm{b}}$ & $12.87 \pm 0.845^{\mathrm{a}}$ \\
Day 4 & $19.43 \pm 0.120^{\mathrm{b}}$ & $19.97 \pm 0.348^{\mathrm{b}}$ & $21.6 \pm 0.321^{\mathrm{a}}$ \\
Day 7 & $25.13 \pm 0.712^{\mathrm{b}}$ & $27.5 \pm 0.208^{\mathrm{a}}$ & $27.03 \pm 0.470^{\mathrm{a}}$ \\
Day 10 & $35.43 \pm 0.578^{\mathrm{b}}$ & $36.3 \pm 0.321^{\mathrm{ab}}$ & $37.37 \pm 0.218^{\mathrm{a}}$ \\
\hline
\end{tabular}

*Different superscript letters in the same line indicate significant difference between means $(\mathrm{p}<0.05)$.

The $\mathrm{pH}$ values of the product ranged from $6.4 \pm$ 0.03 to $6.76 \pm 0.18$ at $+4 \pm 1{ }^{\circ} \mathrm{C}$ during storage. The difference in $\mathrm{pH}$ between the products on the 4 th, 7 th and 10th days of the study was significant $(\mathrm{p}<0.05)$. Time dependent $\mathrm{pH}$ changes in fish cakes are given in Table 8.

Total mesophilic aerobic bacteria values of the products ranged from $4.579 \pm 0.023 \mathrm{log} \mathrm{cfu} / \mathrm{g}$ $\left(3.8 \times 10^{4} \mathrm{cfu} / \mathrm{g}\right)$ to $7.36 \pm 0.049 \quad \log \mathrm{cfu} / \mathrm{g}$ $\left(2.3 \times 10^{7} \mathrm{cfu} / \mathrm{g}\right)$ at $+4 \pm 1^{\circ}$ C. Total mesophilic aerobic (TMA) bacteria counts of the fish cakes were increased depending onstorage time. The difference between total mesophilic aerobic bacteria change between the products on the 1st, 4th, 7 th and 10th days of the study was significant $(p<0.05)$. Time dependent total mesophilic aerobic (TMA) bacteria count changes in fish cakes are given in Table 9.

According to the criteria published by the Ministry of Agriculture and Forestry in terms of total aerobic bacteria content (TMA), the consumption limit of fresh fish meat is $10^{7} \mathrm{cfu} / \mathrm{g}$ (Çolakoğlu et al. 2006). Tench fishcakes reached thelimit on the 10th day. In terms of 
total mesophilic aerobic bacteria content, they maintained their consumable properties until the 10th day.

The total psychrophilic bacteria (TPA) load values of the products were ranged between $3.99 \pm 0.11 \log \mathrm{cfu} / \mathrm{g}\left(1.0 \times 10^{4} \mathrm{cfu} / \mathrm{g}\right)$ and $6.907 \pm 0.014$ $\mathrm{cfu} / \mathrm{g}\left(8.1 \times 10^{6} \mathrm{cfu} / \mathrm{g}\right)$ at $+4 \pm 1^{\circ} \mathrm{C}$. Total psychrophilic aerobic (TPA) bacteria counts of the fish cakes were increased depending on storage time. The difference of total psychrophilic bacterial change between the products on the 1st, 4th, 7th and 10th days of the study was significant $(\mathrm{p}<0.05)$. Time-dependent total psychrophilic aerobic (TPA) bacteria count changes in fish cakes are given in Table 10.

Table 8. Time dependent $\mathrm{pH}$ changes in fish cakes.

\begin{tabular}{cccc}
\hline Days & $\begin{array}{c}\text { Control } \\
\mathbf{x} \pm \text { SH }\end{array}$ & $\begin{array}{c}\text { Group 1* } \\
\mathbf{x} \pm \mathbf{S H}\end{array}$ & $\begin{array}{c}\text { Group 2* }^{*} \\
\mathbf{x} \pm \mathbf{S H}\end{array}$ \\
\hline Day 0 & $6.71 \pm 0.177^{\mathrm{a}}$ & $6.71 \pm 0.072^{\mathrm{a}}$ & $6.76 \pm 0.101^{\mathrm{b}}$ \\
Day 1 & $6.57 \pm 0.074^{\mathrm{a}}$ & $6.63 \pm 0.60^{\mathrm{b}}$ & $6.66 \pm 0.061^{\mathrm{b}}$ \\
Day 4 & $6.53 \pm 0.032^{\mathrm{a}}$ & $6.46 \pm 0.029^{\mathrm{ab}}$ & $6.4 \pm 0.014^{\mathrm{b}}$ \\
Day 7 & $6.63 \pm 0.01^{\mathrm{a}}$ & $6.56 \pm 0.014^{\mathrm{b}}$ & $6.55 \pm 0.015^{\mathrm{b}}$ \\
Day 10 & $6.73 \pm 0.018^{\mathrm{a}}$ & $6.64 \pm 0.017^{\mathrm{b}}$ & $6.62 \pm 0.017^{\mathrm{b}}$ \\
\hline
\end{tabular}

*Different superscript letters in the same line indicate significant difference between means $(\mathrm{p}<0.05)$.

Table 9. Time dependent total mesophilic aerobic (TMA) bacteria changes in fish cakes (log cfu/g).

\begin{tabular}{cccc}
\hline Days & $\begin{array}{c}\text { Control* } \\
\mathbf{x} \pm \mathbf{S H}\end{array}$ & $\begin{array}{c}\text { Group 1* } \\
\mathbf{x} \pm \mathbf{S H}\end{array}$ & $\begin{array}{c}\text { Group 2* } \\
\mathbf{x} \pm \mathbf{S H}\end{array}$ \\
\hline Day 0 & $4.579 \pm 0.013^{\mathrm{a}}$ & $4.616 \pm 0.009^{\mathrm{b}}$ & $4.591 \pm 0.11^{\mathrm{ab}}$ \\
Day 1 & $4.62 \pm 0.009^{\mathrm{a}}$ & $4.663 \pm 0.005^{\mathrm{b}}$ & $4.71 \pm 0.007^{\mathrm{c}}$ \\
Day 4 & $5.263 \pm 0.007^{\mathrm{b}}$ & $5.271 \pm 0.007^{\mathrm{b}}$ & $5.342 \pm 0.011^{\mathrm{a}}$ \\
Day 7 & $6.078 \pm 0.020^{\mathrm{a}}$ & $6.212 \pm 0.023^{\mathrm{b}}$ & $6.372 \pm 0.031^{\mathrm{c}}$ \\
Day 10 & $7.1 \pm 0.030^{\mathrm{b}}$ & $7.192 \pm 0.032^{\mathrm{b}}$ & $7.36 \pm 0.028^{\mathrm{a}}$ \\
\hline
\end{tabular}

*Different superscript letters in the same line indicate a significant difference between means $(\mathrm{p}<0.05)$.

Table 10. Time dependent total psychrophilic aerobic (TPA) bacteria changes in fish cakes $(\log \mathrm{cfu} / \mathrm{g})$.

\begin{tabular}{cccc}
\hline Days & $\begin{array}{c}\mathbf{C o n t r o l}^{*} \\
\mathbf{x} \pm \mathbf{S H}\end{array}$ & $\begin{array}{c}\text { Group 1* } \\
\mathbf{x} \pm \text { SH }\end{array}$ & $\begin{array}{c}\text { Group 2* }^{*} \\
\mathbf{x} \pm \mathbf{S H}\end{array}$ \\
\hline Day 0 & $3.99 \pm 0.063^{\mathrm{b}}$ & $3.994 \pm 0.051^{\mathrm{b}}$ & $4.053 \pm 0.026^{\mathrm{b}}$ \\
Day 1 & $4.115 \pm 0.066^{\mathrm{b}}$ & $4.173 \pm 0.033^{\mathrm{ab}}$ & $4.306 \pm 0.030^{\mathrm{a}}$ \\
Day 4 & $4.999 \pm 0.025^{\mathrm{b}}$ & $5.087 \pm 0.044^{\mathrm{b}}$ & $5.27 \pm 0.020^{\mathrm{b}}$ \\
Day 7 & $5.821 \pm 0.013^{\mathrm{b}}$ & $5.812 \pm 0.019^{\mathrm{b}}$ & $5.931 \pm 0.007^{\mathrm{a}}$ \\
Day 10 & $6.783 \pm 0.010^{\mathrm{a}}$ & $6.845 \pm 0.009^{\mathrm{b}}$ & $6.907 \pm 0.007^{\mathrm{c}}$ \\
\hline
\end{tabular}

*Different superscript letters in the same line indicate significant difference between means $(\mathrm{p}<0.05)$.

Coliform group bacterial load values of the products ranged from $1.36 \pm 0.102 \mathrm{log} \mathrm{cfu} / \mathrm{g}\left(2.3 \times 10^{1}\right.$ $\mathrm{cfu} / \mathrm{g})$ to $2.175 \pm 0.029 \log \mathrm{cfu} / \mathrm{g}\left(1.5 \times 10^{2} \mathrm{cfu} / \mathrm{g}\right)$ at + $4 \pm 1^{\circ} \mathrm{C}$. Coliform bacteria counts of the fish cakes were increased depending on storage time. The difference of coliform group bacterial change between the products on the 1st, 4th, 7th and 10th days of the study was significant $(\mathrm{p}<0.05)$. Time dependent coliform bacteria count changes in fish cakes are given in Table 11.
Yeast and mold load values of the products ranged from $1.56 \pm 0.072 \mathrm{log} \mathrm{cfu} / \mathrm{g}\left(3.6 \times 10^{1} \mathrm{cfu} / \mathrm{g}\right)$ to $2.548 \pm 0.019 \log \mathrm{cfu} / \mathrm{g}\left(3.5 \times 10^{2} \mathrm{cfu} / \mathrm{g}\right)$ at $+4 \pm 1^{\circ} \mathrm{C}$. Yeast and mould counts of the fish cakes were increased depending on storage time. The difference between yeast and mold changes was found to be significant $(p<0.05)$ between the products on the 1st, 4th, 7 th and 10th days of the study. Time dependent yeast and mould count changes in fish cakes are given in Table 12.

Table 11. Time dependent coliform bacteria changes in fish cakes (log cfu/g).

\begin{tabular}{cccc}
\hline Days & $\begin{array}{c}\text { Control* }^{*} \\
\mathbf{x} \pm \mathbf{S H}\end{array}$ & $\begin{array}{c}\text { Group 1* } \\
\mathbf{x} \pm \mathbf{S H}\end{array}$ & $\begin{array}{c}\text { Group 2* } \\
\mathbf{x} \pm \mathbf{S H}\end{array}$ \\
\hline Day 0 & $1.36 \pm 0.058^{\mathrm{b}}$ & $1.46 \pm 0.087^{\mathrm{ab}}$ & $1.519 \pm 0.041^{\mathrm{a}}$ \\
Day 1 & $1.56 \pm 0.041^{\mathrm{b}}$ & $1.634 \pm 0.032^{\mathrm{ab}}$ & $1.725 \pm 0.026^{\mathrm{a}}$ \\
Day 4 & $1.725 \pm 0.026^{\mathrm{b}}$ & $1.752 \pm 0.026^{\mathrm{ab}}$ & $1.823 \pm 0.022^{\mathrm{a}}$ \\
Day 7 & $1.937 \pm 0.17^{\mathrm{b}}$ & $1.969 \pm 0.015^{\mathrm{ab}}$ & $2.014 \pm 0.017^{\mathrm{a}}$ \\
Day 10 & $2.175 \pm 0.011^{\mathrm{b}}$ & $2.111 \pm 0.032^{\mathrm{b}}$ & $2.145 \pm 0.013^{\mathrm{a}}$ \\
\hline
\end{tabular}

*Different superscript letters in the same line indicate significant difference between means $(\mathrm{p}<0.05)$. 
Table 12. Time dependent yeast and mould count changes in fish cakes (log cfu/g).

\begin{tabular}{cccc}
\hline Days & $\begin{array}{c}\text { Control* } \\
\mathbf{x} \pm \mathbf{S H}\end{array}$ & $\begin{array}{c}\text { Group 1* } \\
\mathbf{x} \pm \mathbf{S H}\end{array}$ & $\begin{array}{c}\text { Group 2* } \\
\mathbf{x} \pm \mathbf{S H}\end{array}$ \\
\hline Day 0 & $1.56 \pm 0.0416^{\mathrm{b}}$ & $1.634 \pm 0.032^{\mathrm{ab}}$ & $1.752 \pm 0.026^{\mathrm{a}}$ \\
Day 1 & $1.969 \pm 0.015^{\mathrm{b}}$ & $2.014 \pm 0.013^{\mathrm{ab}}$ & $2.053 \pm 0.026^{\mathrm{a}}$ \\
Day 4 & $2.185 \pm 0.009^{\mathrm{b}}$ & $2.212 \pm 0.018^{\mathrm{b}}$ & $2.328 \pm 0.025^{\mathrm{a}}$ \\
Day 7 & $2.263 \pm 0.007^{\mathrm{b}}$ & $2.286 \pm 0.07^{\mathrm{b}}$ & $2.409 \pm 0.011^{\mathrm{a}}$ \\
Day 10 & $2.437 \pm 0.005^{\mathrm{c}}$ & $2.472 \pm 0.004^{\mathrm{b}}$ & $2.548 \pm 0.010^{\mathrm{a}}$ \\
\hline
\end{tabular}

*Different superscript letters in the same line indicate significant difference between means $(\mathrm{p}<0.05)$.

\section{Discussion}

In this study the processability of tench was tried to be determined. For this purpose some physicochemical and microbiological analysis were conducted to detect quality criteria. Generally, results obtained in this study were in accordance with the similar studies as indicated below.

The panelists reported that; they felt the smell of fish cakes more than fish and they received a pleasant taste due to the effect of spices. These results are in accordance with those reported by Ünlüsayın et al. (2002) in which similar results were obtained from fish cakes.

With the effect of spices and additives used in fish cake production, decrease in water and protein ratios and increase in fat, inorganic and carbohydrate ratios in fish cakes contrast to ground fish were observed. Results were in agreement with Avc1 (1996), who studied physical and chemical changes in trout fish cake and salad during cold storage. In addition, in a study about fish cakes obtained from carp meat conducted by Yanar and Fenercioğlu (1999), reported smilar results.

The TBA results and the results of the fish cakes for day 0 were similar and the values of the control group were found to be lower. This is also an expected condition for raw material. Ünlüsayın et al. (2002) reported that the results of fish cakes obtained from zander and tench were $6.13 \pm 0.39-6.21 \pm 0.48$ for $\mathrm{pH} ; 1.15 \pm 0.97-1.05 \pm 0.54$ for TBA and $0.08 \pm 1.23-10.93 \pm 1$ for TVB-N, orderly. The results obtained from the study show accordance with previous studies.

The products began to deteriorate on the 7th day of the study and exceeded the limit of consumption on the 10th day. It has been observed that TBA analysis findings in the study were in agreement with other studies (Yanar and Fenercioğlu 1999; Ünlüsayın et al. 2002). In a different study, TBA values ranged between 1.70-4.49 (mg MDA $/ \mathrm{kg})$ in the control group and 1.92-3.83 (mg MDA/kg) in the Sunset Yellow FCF supplemented group during storage. The reasons for lower TBA values include factors such as raw material and process differences, such as smoked garfish. (Kaba et al. 2012).
Quality classification of fish and fish products according to TVB-N values are stated as; TVB-N value up to $25 \mathrm{mg} / 100 \mathrm{~g}$ is "very good", up to $30 \mathrm{mg}$ / $100 \mathrm{~g}$ is "good", up to $35 \mathrm{mg} / 100 \mathrm{~g}$ is "marketable" and over $35 \mathrm{mg} / 100 \mathrm{~g}$ is deteriorated. Beside this TVB - N consumable limit value is given as 32-36 $\mathrm{mg} / 100 \mathrm{~g}$ in freshwater fish (Çetinkaya 2017; Varlık et al. 2000). Tench fish cakes could be characterized as "very good" until the 7th day, "marketable" between $7-10$ days and deteriorated after 10 days according to this classification.

In a study about the investigation of some quality parameters of fish cakes made from raw and boiled fish meat, the TVB-N values of the fishcakes made from raw anchovies increased in dependence on the storage period and exceeded the limit value with the values of $39.33 \mathrm{mg} / 100 \mathrm{~g}$ on the 18th day of the first trial and $36.03 \mathrm{mg} / 100 \mathrm{~g}$ on the 15th day of the second trial (Akkuş et al. 2004). In a similar study, TVB-N value of fresh bonito was $10.6 \pm 0.02 \mathrm{mg}$ / $100 \mathrm{~g}$. This value was found to be $12.6 \pm 0.00 \mathrm{mg} / 100 \mathrm{~g}$ on the first day of storage in fishcakes obtained from smoked bonito, and $30.51 \pm 0.09$ at the end of 10 days storage period (Kaba et al. 2013). It was observed that the TVB-N results in the study were consistent with other shelf life of fishcakes determination studies.

$\mathrm{pH}$ values of fish cakes were firstly decreased depending on storage time and then increased. In a study conducted to determine the shelf life of marinated fiscakes, the $\mathrm{pH}$ value of the fishcake marinades stored in the cold was 4.19 at first, but then increased and then decreased depending on the storage time (Varlik et al. 2000).

In the study on the production of fishcakes from fillets of pike perch and tench, $\mathrm{pH}$ values of pike perch and tench fishcakes at $+4 \pm 1^{\circ} \mathrm{C}$ were initially determined as $6.16 \pm 0.02$ and $6.93 \pm 0.42$, respectively. decreased and then increased on the 14th day of the study were determined as $9.12 \pm 0.88$ and $6.78 \pm 0.09$, respectively, during the study period, it decreased firstly and then increased to $9.12 \pm 0.88$ and $6.78 \pm 0.09$ on the 14th day of the study, respectively (Ünlüsayın et al. 2002).

In our study, changes in $\mathrm{pH}$ values of fishcakes during 10 days storage were found to be acceptable. 
In general, fresh fish $\mathrm{pH}$ value is reported to be 6.06.5, consumability limit value is 6.8-7.0 (Gökoğlu and Varlık 1992; Akkuş et al. 2004). The pH values are also in line with the results of the study in which Öksüztepe et al. (2010) examined the effect of sodium lactate addition on fish cakes.

In the study on microbiological quality of fresh and processed atherina fish (Atherina boyeri, Risso 1810), the average total aerobic bacteria count and coliform bacteria count in fresh fish were reported as $2.2 \times 101 \mathrm{cfu} / \mathrm{g}$ and $2.9 \times 101 \mathrm{cfu} / \mathrm{g}$, respectively. In the study on the production of fishcakes from fillet residues of pike perch and tench, total mesophilic aerobic bacterial values of pike perch and tench fishcakes were initially determined as $4.0 \times 10^{4} \mathrm{cfu} / \mathrm{g}$ and $4.2 \times 10^{4} \mathrm{cfu} / \mathrm{g}$, respectively, then increased on the 14th day of the study and determined as $1.2 \times 10^{7} \mathrm{cfu} / \mathrm{g}$ and $1.4 \times 10^{7} \mathrm{cfu} / \mathrm{g}$, respectively (Ünlüsayın et al. 2002).

In the study of the examination of some quality parameters of fishcakes made from raw and boiled fish meat, total mesophilic aerobic bacteria value of fishcakes made from raw anchovy increased depending on the storage time and the value in the first trial at the beginning of storage was found to be $4.8 \pm 0.007 \log \mathrm{cfu} / \mathrm{g}$ and in the second trial it was $4.6 \pm 0.021 \log \mathrm{cfu} / \mathrm{g}$. On the 12 th day of the storage, the value in the first trial was found to be $7.4 \pm 0.014$ $\log \mathrm{cfu} / \mathrm{g}$ and in the second trial it reached to $7.3 \pm 0.002 \log \mathrm{cfu} / \mathrm{g}$ and exceeded the limit value (Akkuş et al. 2004). In the study on the shelf life of anchovy fishcakes stored in cold, total mesophilic aerobic bacteria value increased by storage time and was determined as $4 \log \mathrm{cfu} / \mathrm{g}\left(1.0 \times 10^{4} \mathrm{cfu} / \mathrm{g}\right)$ at the beginning of storage and reached $7.76 \mathrm{log} \mathrm{cfu} / \mathrm{g}$ $\left(5.8 \times 10^{7} \mathrm{cfu} / \mathrm{g}\right)$ value on the 10 th day of storage (Turhan et al. 2001).

The total psychrophilic bacteria (TPA) all samples remained below the limit of $10^{7}$. In the study of the examination of some quality parameters of fishcakes made from raw and boiled fish meat, total psychophilic bacterial load value of fishcakes made from raw anchovy increased depending on the storage time and in the first trial at the beginning of storage, it was found to be $4.0 \pm 0.001 \log \mathrm{cfu} / \mathrm{g}$ and in the second trial it was $4.5 \pm 0.004 \log \mathrm{cfu} / \mathrm{g}$. On the 12th day of the storage, the value in the first trial was found to be $7.7 \pm 0.002 \mathrm{log} \mathrm{cfu} / \mathrm{g}$ and in the second trial it reached to $7.8 \pm 0.014 \log \mathrm{cfu} / \mathrm{g}$ and exceeded the limit value (Akkuş et al. 2004).

Bacterial content of coliform group, which is an indicator of the hygienic quality of the product, was determined below the limit value of $2.1 \times 10^{2} \mathrm{cfu} / \mathrm{g}$ given in all three sample types (Anonymous, 2002; Çolakoğlu et al., 2006). In the study on the shelf life of anchovy fishcakes stored in cold, bacterial value of coliform group increased depending on storage time and it was determined as $1.3 \mathrm{log} \mathrm{cfu} / \mathrm{g}\left(2.0 \times 10^{1}\right.$ $\mathrm{cfu} / \mathrm{g})$ at the beginning of storage and reached 4.84 $\log \mathrm{cfu} / \mathrm{g}\left(6.9 \times 10^{4} \mathrm{cfu} / \mathrm{g}\right)$ on 10th day of storage (Turhan et al. 2001).

Yeasts and molds are not found in normal flora in fish. These microorganisms are generally of soil origin and are known to be contaminated with water at the time of hunting or the tools and materials used after hunting (Göktan 1990; Patır and Duman 2006). It is thought that the yeast and mold detected in the products may be contaminated from the environment during processing or from the refrigerator where the storage is made.

The freshwater of Turkey has a large population in terms of tench (T. tinca). These fish are usually consumed as fresh in the regions where they are fishing, while some of them are filleted in the processing plants and put on the market. Due to the fact that both having less knowledge about the tench and having low demand for frozen fish, the fish is sold at a very low price and consumed in a small amount. In this study to increase fish consumption and offer different products to the consumers, the products obtained have been highly appreciated and a different taste has been revealed.

The results of the microbiological analysis obtained in this study are in accordance with the literature. According to the results of microbiological analysis, the fishcakes obtained in the study exceeded the limit values after the 10th day. It is estimated that the microbiological analysis results of the group 2 fishcakes were high and these values were statistically significant $(\mathrm{p}<0.05)$ due to the high microbial load of the ginger used at the beginning.

As a result, the fish cakes obtained from the tench fish were maintained the edible property until the 10th day and then spoiled according to the results of chemical and microbiological analysis. Fish cakes could be stored in aluminum packaging for 10 days under refrigerator conditions at $4 \pm 1{ }^{\circ} \mathrm{C}$, but the first 7 days of storage is classified as good quality class for the products. In addition, in the light of the findings obtained, a new product variety and consumer taste is presented with a different flavor, and the shelf life of the fish cake obtained from the tench has also been determined.

\section{References}

Akkuş Ö, Varlık C, Erkan N, Mol S. 2004. Determination of some quality parameters of fishballs prepared from raw and boiled fish. Turk $\mathrm{J}$ Vet Anim Sci. 28(1):79-85.

Anonymous, 1974a. Et ve et mamulleri rutubet miktan tayini, TS 1743, Türk Standartları Enstitüsü, Ankara.

Anonymous, 1974b. Et ve et mamulleri kül tayini, TS 1746, Türk Standartları Enstitüsü, Ankara. 
Anonymous, 1983. G1da maddeleri muayene ve analiz yöntemleri kitabı. Yay. No: 65, Özel Yayın No: 62105. Ankara: T.C.T.O.K.B. Gıda İşleri Genel Müd. $796 \mathrm{~s}$.

Anonymous, 1993. Gida sanayinde mikrobiyoloji ve uygulamaları, Yay. No: 124. Kocaeli: TÜBİTAK Marmara Araştırma Merkezi Gıda ve Soğutma Teknolojisi 216s.

Anonymous, 2002. Tarım ve Köyişleri Bakanlığı Su Ürünleri Yönetmeliği, 14.11.2002 Tarih ve 24936 Sayılı Resmi Gazete

Antonacopoulos N, Vyncke W. 1989. Determination of volatile basic nitrogen in fish: A third collaborative study by the West European Fish Technologists Association (WEFTA). Zeitschrift Fur LebensmittelUntersuchung Und-Forschung. 189:309-316.

Avc1 İ. 1996. Alabalık (Oncorhynchus mykiss) köfte ve salatasının soğukta depolanmasındaki fiziksel ve kimyasal değişimlerinin incelenmesi [Yüksek Lisans Tezi]. İstanbul Üniversitesi. $64 \mathrm{~s}$.

Avlijaš S, Ricciardi A, Mandrak NE. 2018. Eurasian tench (Tinca tinca): the next Great Lakes invader. Can J Fish Aquat Sci. 75:(2):169-179. doi: 10.1139/cjfas-2017-0171

Balıkçı E, Akın G, Yavuzer E. 2018. Effects of some plant and spice extracts on the quality of fish balls in gastronomy. Journal of Tourism and Gastronomy Studies 6/Special issue 3:197-210. doi: 10.21325 /jotags. 2018.248

Çetinkaya S. 2017. The marinat technology and impact of marination on quality properties of aquatic products. LimnoFish. $\quad 3(2): 117-128$. doi: 10.17216/limnofish.321883

Çolakoğlu FA, Ova G, Köseoğlu B. 2006. Taze ve işlenmiş Gümüş Balığının (Atherina boyeri Risso, 1810) mikrobiyolojik kalitesi. EgeJFAS. 23(1/3):393-395

Damarlı E, Varlık C, Pala M. 1992. Hazır yemek teknolojisinde su ürünlerinin yeri. Su ürün. Avl. ve İşi. Tek. Seminer Tebliğleri. İstanbul: İstanbul-Beyoğlu Rotary Klubü 140 s.

Dikel S, Çelik M. 1998. Aşağı Seyhan Havzası'nda yakalanan tatlı su Çipurası'nın (Tilapia ssp.) yenilebilir ve yenilemez bölümlerinin ağırlık oranlan ile bazı besin öğelerinin belirlenmesi. Türk Vet. ve Hayvancılık Dergisi. 22(6):517-520.

Duman M, Dartay M. 2007. Changes in meat yield and chemical composition of Mirror carp (Cyprinus carpio l.,1758) fillets after hot-smoked. Doğu Anadolu Bölgesi Araştırmaları. 186-190.

Duman M, Özpolat E. 2012. Chemical and sensory quality changes of different formulated Inegöl fish balls, made from Capoeta trutta (Heckel, 1843) during froze storage. Gida 37(1):25-31.

Er B. 2010. Ton balığ 1 konservelerinde katı faz ekstraksiyon ve HPLC metodu ile bisfenol-a varlığının incelenmesi [Doktora Tezi]. Ankara Üniversitesi. $88 \mathrm{~s}$.

Gökoğlu N, Varlık C. 1992. Balıklarda rigor- mortis ve kalite üzerine etkisi. Su Ürünleri Avlama ve İşleme Teknolojisi Seminer Tebliğleri. İstanbul Beyoğlu Rotary Kulübü Yayınları, No 14:98-102.
Göktan D. 1990. Gıdaların mikrobiyal ekolojisi, Cilt 1. Et Mikrobiyolojisi. İzmir: Ege Üniversitesi Basımevi $292 \mathrm{~s}$.

Hamalosmanoğlu M, Kuru M. 2004. Karyotype analyses of the Tench (Tinca tinca L., 1758) living in Lake Mogan (Ankara). Turk J Vet Anim Sci. 28(1):143147.

Haq M, Dutta PL, Sultana N, Rahman Md.A. 2013. Production and quality assessment of fish burger from the grass carp, Ctenopharyngodon idella (Cuvier and Valenciennes, 1844). Journal of Fisheries 1(1):42-47.

İnal T. 1992. Besin hijyeni. Hayvansal gıdaların sağlık kontrolü. Genişletilmiş 2. Baskı. İstanbul: Final Ofset $783 \mathrm{~s}$.

Kaba N, Özer Ö, Çorapçı B. 2012. The determination of some quality parameters of smoked gar fish meat balls. Journal of Fisheries Sciences.com. 6(4):357367.

Kaba N, Çorapçı B, Yücel Ş, Özer Ö, Eryaşar K. 2013. Sensory, chemical and microbiological properties of smoked Bonito ball (Sarda sarda, Bloch 1793). Akademik Gida 11(2):45-50.

Keskin H. 1975. Gıda Kimyası, İstanbul Üniv. Yayını Sayı: 1980, Kimya Fak., No:21, İstanbul, 1046 s.

Kocatepe D, Taşkaya G, Kaya Y, Turan H, Erkoyuncu İ. 2011. Farklı balıç̧ı tezgâhlarının mikrobiyolojik yönden incelenmesi. Biyoloji Bilimleri Araştırma Dergisi 4(2):73-77.

Öksüztepe G, Çoban ÖE, Güran HŞ. 2010. The effect of addition of sodium lactate in fish balls made from fresh rainbow trout (Oncorhynchus mykiss W.). Kafkas Üniv Vet Fak Derg. 16 (Suppl-A):65-72.

Özpolat E, Çoban ÖE. 2012. The effect of different storage temperatures on the chemical qualities of fishballs prepared from Capoeta trutta (Heckel, 1843) and Capoeta umbla, (Heckel, 1843). Ege J Fish Aqua Sci. 29(3):127-131. doi: 10.12714/egejfas.2012.29.3.04

Patır B, Duman M. 2006. Tütsülenmiş Aynalı Sazan (Cyprinus carpio L.) filetolarının muhafazası sırasında oluşan fiziko-kimyasal ve mikrobiyolojik değişimlerin belirlenmesi. F.Ü Fen ve Müh Bil Derg. 18(2):189-195.

Refai MK. 1979. Manual of food quality control: No 4. microbiology analysis. Rome: Food and Agriculture Organization of the United Nations (FAO) $144 \mathrm{~s}$.

Secci G, Parisi G, Meneguz M, Iaconisi V, Cornale P, Macchi E, Gasco L, Gai F. 2018. Effects of a carbon monoxide stunning method on rigor mortis development, fillet quality and oxidative stability of tench (Tinca tinca). Aquaculture. 498:233-239. doi: 10.1016/j.aquaculture.2018.05.002

TSE 2002. Türk Standartları enstitüsü. Et ve Et Ürünleri pH Ölçülmesi, TS 3136, Ankara: TSE Yayınları

Turhan S, Evren M, Yazıc1 M. 2001. Soğukta muhafaza edilen hamsi (Engraulis encrasicholus) köftelerinin raf ömrü. E.Ü. Su Ürün Derg. 18(3-4):391-398.

Ünlüsayın M, Bilgin Ş, İzci L, Gülyavuz H. 2002. Sudak (Sander Lucioperca L. Kottelat, 1997) ve Kadife Tinca tinca L. 1758) balığı fileto artıklarından köfte yapımı ve raf ömrünün belirlenmesi. 
SDÜ Fen Bil Enst Derg. 6(3):25-34.

Varlık C, Erkan N, Metin S, Baygar T, Özden Ö. 2000. Marine balık köftesinin raf ömrünün belirlenmesi. Turk $\mathrm{J}$ Vet Anim Sci. 24:593-597.

Varlık C, Uğur M, Gökoğlu N, Gün H. 1993.
$\mathrm{Su}$ ürünlerinde kalite kontrol ilke ve yöntemleri. Yayını No: 17. İstanbul: Gıda Teknolojisi Derneği $174 \mathrm{~s}$.

Yanar YH, Fenercioğlu H. 1999. The utilization of carp (Cyprinus carpio) flesh as fish ball (in Turkish). Turk J Vet Anim Sci. 23:361-365. 